臭素，塩素およびホウ素変性によるフェノール樹脂 の耐燃, 耐熱性の向上 ${ }^{\dagger}$

広畑 健* 三崎敏 一* 吉 井 稔*

\title{
Bromine, Chlorine and Boron Modified Phenolic Resins with Excellent Flame Retardance and Thermal Stability \\ by
}

\section{Takeshi Hirohata*, Toshikazu Misaki* and Minoru Yoshiı*}

Bromine (BRP) or chlorine modified phenolic resins (CLP) were prepared by the reaction of paraharogenated phenol-phenol mixtures with formaldehyde. Boron modified phenolic resins (PBP) were prepared by the esterification of boric acid with phenol, followed by the polycondensation with paraformaldehyde.

The flame retardance of the modified resins was evaluated in comparison with the unmodified resin (GP) by the measurement of oxygen index, and found to be in the order: $\mathrm{BRP}>\mathrm{PBP}>\mathrm{CLP}>$ GP.

The higher was the heat-treatment temperature, the higher was the heat distortion temperature (HDT) of resin. The HDT of resin was in the order: PBP, GP>BRP $>$ CLP. This order was the same as the results of flexual properties.

The resistance against thermooxidative degradation of the resins was examined by means of thermogravimetry and differential thermal analysis, and the higher resistance was observed by the order of $\mathrm{PBP}>\mathrm{GP} \fallingdotseq \mathrm{CLP} \gg \mathrm{BRP}$.

キー・ワード：ハロゲン変性フェノール樹脂, ホウ酸フェニル樹脂, 耐燃性, 耐熱性, 而酸化熱分解性

\section{1 緒言}

フェノール樹脂は耐燃, 耐熱性に優れ, しかも安価 なことから各種産業分野で使われている.しかし最近 ますます耐燃，耐熱性への要求は䩦しいものになりつ つ㐫る。

樹脂の耐燃性を向上させる目的でよく用いられてい る添加型難燃剤はブリード，それに機械的，電気的性 質や耐熱性の低下といら問題があるため，使用に当た り，これら物性の低下を極力抑克る必要がある.

反応型難燃剂にはこれらの欠点が少ないが, 反応型 難燃剂の多くがハロゲン原子を含むため, 熱分解時に 有害がスの発生が避けられない。これに対して, 樹脂 に無機分子構造を化学結合させたものは, 耐熱性の向 上とともに耐燃性にも寄与し，熱分解時の発生ガスも 無害であると期待される。しかし現在のところ無機分 子構造を化学結合したフェノール樹脂に関する研究は 少ない。

本報告では， p-クロロフェノールまたは p-ブロモ フェノールとフェノールの共縮合した樹脂を合成した。 また，ホウ酸とフェノールをエステル化させて，ホウ 酸フェニルを得, このものよりホウ酸ェステルタイプ のフェノール樹脂を合成した，そして得られた樹脂の
構造および置換原子と物性との関係について検討した

$$
2 \text { 実 }
$$

験

\section{$2 \cdot 1$ 試薬}

p-クロロフェノール，フェノール，パラホルムアル デヒド，35\%ホルムアルデヒド水溶液，木ウ酸，水酸 化ナトリウム，モノメチルアミン，塩酸は市販 1 級品 をそのまま使用した。 $\mathrm{p}$ ーブロモフェノールは市販の 試薬特級品を用いた。

\section{$2 \cdot 2 \mathrm{p}$-ハロゲン化フェノールーフェノール 共縮合} 樹脂の合成

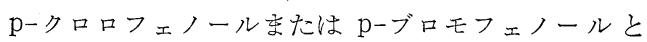
フェノールの混合フェノール1モルに対してホルムア ルデヒドが 1.8 モルとなるように $35 \%$ ホルムアルデヒ ド水溶液と $0.05 モ ル の$ 水酸化ナトリウムを加光，80〜 $90^{\circ} \mathrm{C} て ゙ 3$ 時間かきまぜながら反応させた，反応終了後 2 時間減圧下で脱水濃縮したものを 2 枚の強化ガラス 板で作った型に注入し， $40^{\circ} \mathrm{C} て ゙ 24$ 時間， $70^{\circ} \mathrm{C} て ゙ 72$ 時間 加熱して硬化させた．以下 $\mathrm{p}$ クロロフェノールーフェ ノール共縮合樹脂を CLP, p-ブロモフェノールーフェ ノール共縮合樹脂を $\mathrm{BRP}$ ，両者を総称した $\mathrm{p}$-ハロゲ ン化フェノール (PHP) -フェノール共縮合樹脂をPH$\mathrm{PP}$ と略記する。また総つェノールに対するPHP の

†原稿受理 昭和61年5月26日 Received May 26, 1986

* 正会 員 大阪府立工業技術研究所 東大阪市高井田中, Osaka Prefectural Industrial Research Institute, Takaida-naka, Higashi-Osaka 
割合（重量\%）を示すときには， CLP(10)～CLP(50), $\operatorname{BRP}(10) \sim \operatorname{BRP}(50)$ のように表す.

\section{$2 \cdot 3$ 木ウ酸フェニル樹脂の合成}

ホウ酸 1 モルに対し，1.5〜3.0モルのフェノールを 加光，室温より徐々に加熱して反応させた。 8 時間か けて $300^{\circ} \mathrm{C}$ に， $300^{\circ} \mathrm{C} て ゙ 7$ 時間反応させた. エステル 化反応が進むにつれて水が生成するので，未反応フェ ノールとともに留去し反応を促進させた. エステル化 反応終了後 $60 \sim 80^{\circ} \mathrm{C}$ ま゙温度を下げ，フェノール 1 モ ルに対しホルムアルデヒド 1.5 モルになるようにパラ ホルムアルデヒドを少しずつ加党, 発熱反応が治まっ てから $150^{\circ} \mathrm{C}$ で加熱し樹脂化した。このプレポリマ 一の状態のときに注型し， $80^{\circ} \mathrm{C} て ゙ 24$ 時間，さらに 100 ${ }^{\circ} \mathrm{C}$ で24時間硬化させて樹脂板を作製した.

\section{$2 \cdot 4$ 硬化樹脂の物性測定}

酸素指数の測定は，東洋精機(株)製キャンドル法燃 焼試験機を用い, JIS-K7201 に従って行った。

熱変形温度 (HDT) は, ASTM-D648 に従い, 東洋 精機(株)製荷重たわみ温度試験機を用いて，曲げ応力 $1.81 \mathrm{MPa}$ ，昇温速度 $2^{\circ} \mathrm{C} / \mathrm{min}$ の条件下で測定した。

曲げ試験は，インストロン材料試験機1114型を用い, 試験片形状 $6.0 \times 13 \times 110 \mathrm{~mm}$ ，スパン $100 \mathrm{mm，ク口}$ スヘッド速度 $2 \mathrm{~mm} / \mathrm{min}$ にて行い，5点の平均值で 結果を示した.

熱分析は理学電機(株)製 TG-DTA 標準型を用い, 試料重量 $7 \sim 9 \mathrm{mg}$, 昇温速度 $10^{\circ} \mathrm{C} / \mathrm{min}$, 静止空気雾 囲気中の条件下で熱重量分析 (TG) と示差熱分析 (D

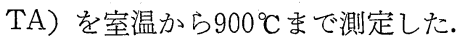

各試料の熱処理には熱風循環式乾燥機を゙用いた。

\section{3 結果および考察}

\section{$3 \cdot 1$ ホウ酸フェニルの推定一般構造式}

ホウ酸と過剩のフェノールを反応させると Fig. 1 に示す $N$ のよらなホウ酸トリフェニルができる。ボ 酸に対してフェノールの割合が少なくなると，Fig.1 のI〜Nのよらなホウ酸とフェノールのェステルの混 合物ができると考えられている. これから一般式 $\mathrm{BO}_{x}$ $\left(\mathrm{OC}_{6} \mathrm{H}_{5}\right)_{y}$ または $\mathrm{B}(\mathrm{OH})_{x}\left(\mathrm{OC}_{6} \mathrm{H}_{5}\right)_{y}$ が提唱されてい

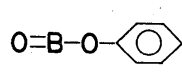

(I)<smiles>OB1Oc2ccccc2O1</smiles>

(III)

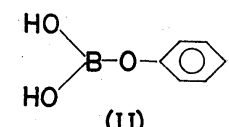

(II)

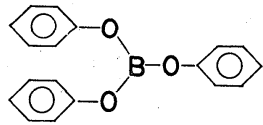

(IV)
Fig. 1. Proposed structure of reaction products of boric acid with phenol.
るが，ここでは $\mathrm{BO}_{k}(\mathrm{OH})_{l}\left(\mathrm{OC}_{6} \mathrm{H}_{5}\right)_{m}$ で表すことにす る.

生成した水と末反応フェノールを定量することによ り, Table I に示すようなホウ酸フェニルが得られた. これらをパラホルムアルデヒドと反応させて樹脂化し たものをとれぞれ PBP(1) PBP(4) で示す(Table I).

Table I. Preparation of phenyl borates and their condensation resins with paraformaldehyde.

\begin{tabular}{c|c|ccc|c}
\hline Run & $\begin{array}{l}\text { Phenol/ } \\
\text { Boric acid } \\
\text { molar } \\
\text { ratio }\end{array}$ & \multicolumn{3}{|c|}{ Phenyl borate } & Oxygen \\
index
\end{tabular}

a) $\mathrm{BO}_{k}(\mathrm{OH})_{l}\left(\mathrm{OC}_{6} \mathrm{H}_{5}\right)_{m}$

\section{$3 \cdot 2$ 耐燃性}

樹脂中にハロゲンが存在すると耐燃性が増加すると 考えられる，そこで今回合成した PHPP の酸素指数 に及ぼすハロゲンやホウ酸フェニル樹脂のホウ素の影 響について調べた。

Fig. 2 に PHPP の組成比と酸素指数の関係を示す. 同一重量の PHP の含有量で比較すると BRP は CLP に比べて約10倍有効であった．またホウ酸フェニル樹 脂は未変性フェノール樹脂（以下 GP と略記）の酸素 指数55に比べて有効であったが，その構造が耐然性に 及ぼす影響は小さかった (Table I).

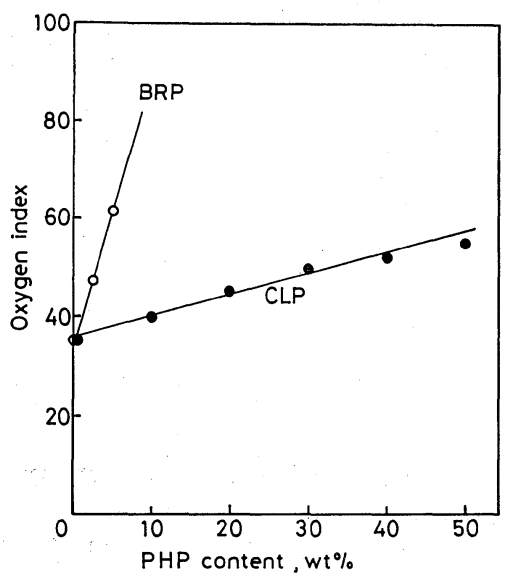

Fig. 2. Effect of p-halogenated phenol (PHP) content on oxygen index in $\mathrm{p}$-halogenated phenol-phenol copolymers.

以上より耐燃性に及ぼす変性樹脂の効果は, BRP> $\mathrm{PBP}>\mathrm{CLP}>\mathrm{GP}$ の順であった.

\section{$3 \cdot 3$ 熱処理の影響}

3・3・1 ホウ酸フェニル樹脂の外観の変化 4 種 類のホウ酸ブェニル樹脂のプレポリマーを室温下で放 
置してて硬化させたものはすべて灰緑色であった。こ就 を $120^{\circ} \mathrm{C} て ゙ 5$ 時間熱処理すると鮮やかな黄色淿なり， $200^{\circ} \mathrm{C}, 5$ 時間では $\mathrm{PBP}(1)$ ） $\mathrm{PBP}(3)$ が黄褐色, $\mathrm{PBP}(2)$ は黄色, PBP(4) は褐色とな的た。 $250^{\circ} \mathrm{C}$, 5 時間では $\mathrm{PBP}(1)$ と $\mathrm{PBP}(3)$ が緑褐色, $\mathrm{PBP}(2)$ は黄褐色, PBP(4) は褐色でめった。

これに対して GP を室温で硬化させたものは白色で あり， $120^{\circ} \mathrm{C} ， 5$ 時間では朱色となり，150 ${ }^{\circ} \mathrm{C} ， 5$ 時間 で褐色となった。 $200{ }^{\circ} \mathrm{C}$ 以上では表面の色は黒色とな り炭化が始まっていることが暗示された。すすなわちホ ウ酸フェニル樹脂では GP に比べて高温下に接敄る色 の変化が少なかった. なかでも $\mathrm{PBP}(2)$ の着色の程度 はわずかであった。

$3 \cdot 3 \cdot 2$ HDT に及ぼす影響 熱硬化性樹脂では 熱処理温度が高い程硬化が進み, 物理的, 化学的耐熱 性が向上することが知られている.

$180^{\circ} \mathrm{C} ， 5$ 時間熱処理したPHPPの共縮合比が HDT に及ぼす影響を Fig. 3 に示す. いずれの共縮合比に おいてる BRP の方が CLP より約 $10^{\circ} \mathrm{CHDT}$ が高か った. しかしながら PHP の割合が多くなると HDT が低下するのは PHP はフェノール樹脂の反応性のあ るベンゼン環のオルソ, パラ位置のうち, オルソ位置 のみの 2 官能性のため十分に架橋が進まないためと考 党らる。

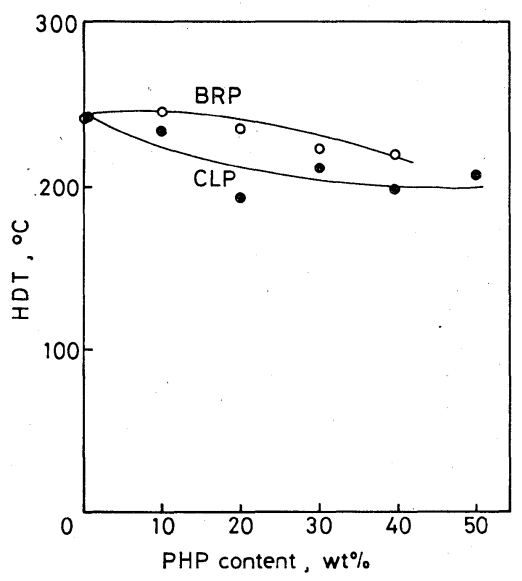

Fig. 3. Heat distortion temperature (HDT) vs. p-halogenated phenol (PHP) content in modified phenolics after heat-treatment at $180^{\circ} \mathrm{C}$ for $5 \mathrm{hr}$.

Fig. 4 は共縮合比 $50 \mathrm{wt} \%$ の樹脂を各温度で，それ ぞれ 5 時間熱処理したものの熱処理温度と HDT の関 係を示す. BRP の方が CLP よりも HDT が高いこ とがわかる。

ホウ酸フェニル樹脂の熱処理条件と HDT の関係を 調ベた. 結果を Table II に示す。 $150^{\circ} \mathrm{C} ， 24$ 時間の 熱処理では，4種類のホウ酸フェニル樹脂の HDT は

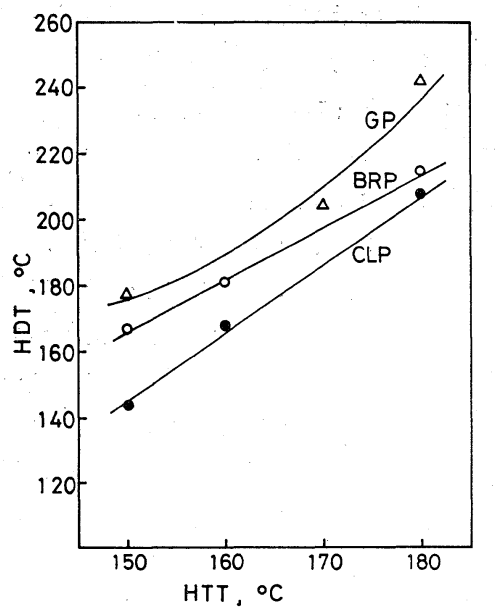

Fig. 4. Relation between HDT and heat-treatment temperature (HTT) in PHP (50) modified phenolics.

Table II. Heat distortion temperature (HDT) of phenyl borate resins.

\begin{tabular}{l|r|r|r|r|r}
\hline \multirow{2}{*}{$\begin{array}{l}\text { Heat } \\
\text { treatment } \\
\text { conditions }\end{array}$} & \multicolumn{5}{|c}{ HDT ( $\left.{ }^{\circ} \mathrm{C}\right)$} \\
\cline { 2 - 6 } & GP & PBP (1) & PBP (2) & PBP (3) & PBP (4) \\
\hline $150^{\circ} \mathrm{C}, 24 \mathrm{hr}$ & 240 & 164 & 175 & 189 & 194 \\
$200^{\circ} \mathrm{C}, \quad 5 \mathrm{hr}$ & $>250$ & 193 & $>250$ & $>250$ & $>250$ \\
$250^{\circ} \mathrm{C}, \quad 5 \mathrm{hr}$ & - & $>250$ & $>250$ & $>250$ & $>250$ \\
\hline
\end{tabular}

かなり異なり，また GPよりも低かったが，熱処理 温度を高めるにつれ, いずれも HDT は $250^{\circ} \mathrm{C}$ 以上に なった。これはホウ酸フェニル樹脂では,フェノール とホウ酸のエステル結合の結果, ベンゼン環のオルン, パラ位置の電子密度が変化したり, ホルムアルデヒド が結合する際に立体障害を受けたりして，GP に比べ て三次元硬化し難いためと考光られる.

$3 \cdot 3 \cdot 3$ 曲げ特性 ホウ酸フェニル樹脂と GP の 熱処理温度と曲げ特性の関係を Fig. 5 に示す。，熱処 理は $100{ }^{\circ} \mathrm{C} ， 24$ 時間硬化したものをそれぞれの温度で 5 時間加熱することにより行った. Fig. 5 より曲げ強 さは熱処理温度 $150^{\circ} \mathrm{C}$ 付近で最大となった.

GP では熱処理温度が $200^{\circ} \mathrm{C}$ 以上になると黒化し, $250^{\circ} \mathrm{C}$ 以上ではフクレや割れが多く生じたが，ホウ酸 フェニル樹脂では $200^{\circ} \mathrm{C}$ 以上でる劣化の度合は外観拝 よび曲げ強さからみて GP に比べて小さかった.

曲げ弾性率はモノメチルアミン触媒の GP の場合熱 処理により大きく変化したが，ホウ酸フェニル樹脂と 塩酸触媒の GP ではほとんど変化しなかった。

モノメチルアミン触媒で合成した GP は塩酸触媒で 合成したものに比べて熱処理による曲げ強さの低下の 度合いが大きく, 曲げ弾性率の挙動も違う。これはア 


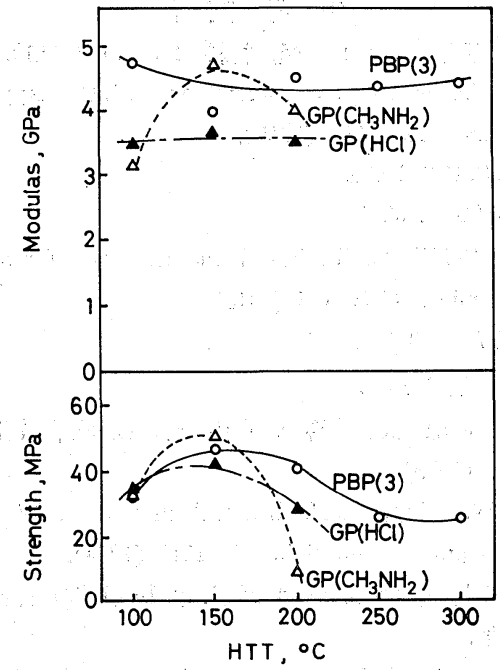

Fig. 5. Rèlation between flexual properties and HTT.

ミン系触媒ではメチレンエーテル架橋の割合が多く， 塩酸触媒ではメチレン架橋の割合が多いためと考えら れる。

ハロゲン系樹脂である BRP と CLP では熱処理温 度 $200^{\circ} \mathrm{C}$ 以上では割れやフクレが多いため $150^{\circ} \mathrm{C} て ゙$ 熱処 理したものについて調べた. 曲げ強さは BRP が30〜 $43 \mathrm{MPa}$ に対し CLP は 25〜39 $\mathrm{MPa}$ となり, BRP の方が若干大きかったが GP よりは小さかった.

\section{$3 \cdot 4$ 熱分解性}

Fig. 6 に各フェノール 樹脂の 静止空気雾团気中の TG 曲線を示す. TG 曲線に执いて熱分解の初期での 樹脂間の差はないが，高温になる程ホウ酸フェニル樹 脂の耐熱分解安定性が良いことがわかる. 八ロゲン系 樹脂では BRP(50) の方が $\operatorname{CLP}(50)$ に比べて低温で 熱分解した。 BRP は CLP より耐燃性が非常に優れ

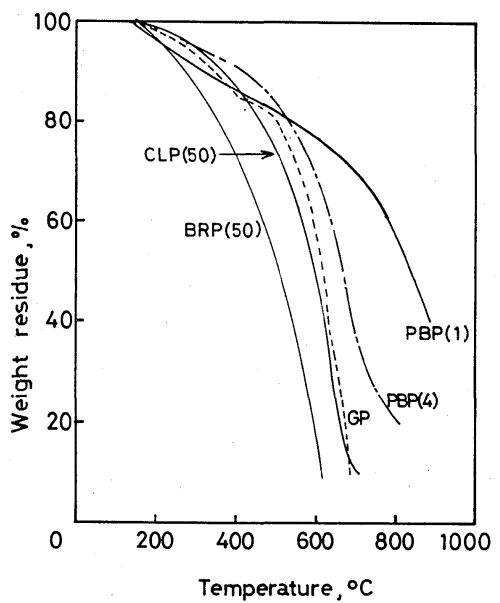

Fig. 6. Thermogravimetric curves of modified phenolics.
ていたことから，含ハロダン系樹脂においては熱分解 を受けやすい方が耐然性に有効であることがわかる. この理由として，C-Brの解離エネルギが $54 \mathrm{kcal} / \mathrm{mol}$ に対し $\mathrm{C}-\mathrm{Cl}$ の解離エネルギは $67 \mathrm{kcal} / \mathrm{mol}$ で岗り, 臭素系樹脂の方が塩素系樹脂よりも解離エネルギが小 さく，同じ熱エネルギでは臭素系樹脂の方が速く分解 して, $\mathrm{Br}_{2}$ や $\mathrm{HBr}$ を発生し，これが樹脂の熱分解に よって生じる可然性ガスを希釈したり，ラジカル機構 で進行する燃焼反応の連鎖反応を停止するためである。

同様な結果は DTA の酸化分解発熱ピークからもわ かる. Fig. 7. は酸化分解発熱ピークを試料 $1 \mathrm{mg}$ に換 算して比較したものである。 BRP、の酸化発熱量は大 きく，そのピークは低温で始まっていることから耐酸 化熱分解性が低いことがわかる。これに対して CLP ではGPとあまり差はみられない，逆に小ウ酸フェ二 ル樹脂の場合には酸化発熱量は小さく，しかもそのピ ークが高温側にずれていることがわかる．特に PBP （1）の場合にこの傾向が強く，TG 曲線の結果を含め て耐酸化熱分解性が優れていることがわかる.

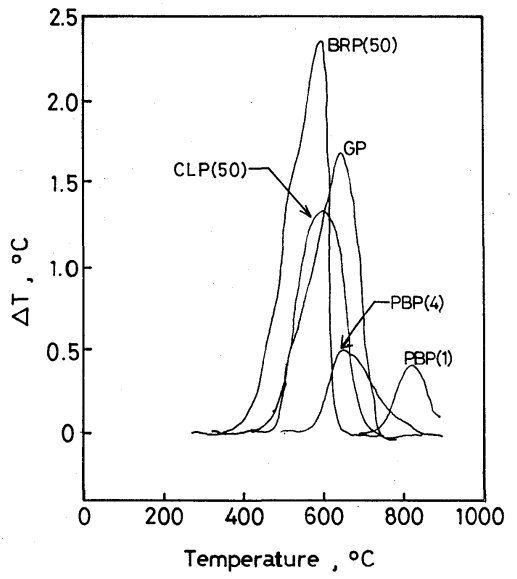

Fig. 7. DTA curves of modified phenolics per $1 \mathrm{mg}$.

フェノール樹脂を非酸化雾囲気中で熱分解させると 残炭率が高いことは知られている. しかし空気中，高 温下では酸化熱分解してしまらことが Fig. 6，7.より 示された. ホウ酸フェニル樹脂を高温で熱分解すると 炭化物とガラス状のものが目視により観察された。 こ のガラス状のものは，融点拈よび赤外線吸収スペクト ル, アルコール，水などへの溶解試験により $\mathrm{B}_{2} \mathrm{O}_{3}$ と 推定した.これから，ホウ酸フェニル樹脂が耐酸化熱 分解性に優れているのは熱分解時に炭化物と $\mathrm{B}_{2} \mathrm{O}_{3}$ が 生じ，この $\mathrm{B}_{2} \mathrm{O}_{3}$ が酸化防止に働くためと考えた。

\section{4 結言}

耐燃，耐熱性の向上を目的として，5種類の塩素ま たは臭素を含有するフェノール系共縮合樹脂抏よび 4 
種類のホウ酸フェニル樹脂を合成し，物性に与える影 響について検討したところ以下のようであった。

（1）耐燃性が最も優れている樹脂は臭素系樹脂であ った. ホウ酸フェニル系樹脂間での酸素指数にはあま り差がなかった．また変性フェノール樹脂の耐然性に 与える効果は $\mathrm{BRP}>\mathrm{PBP}>\mathrm{CLP}>\mathrm{GP}$ の順であった.

（2）熱処理温度が高い程熱変形温度は高くなった。 しかしホウ酸フェニル樹脂では未変性フェノール樹脂 に比べてより高い熱処理温度が必要であった.

（3）熱処理温度 $150^{\circ} \mathrm{C}$ 付近で曲げ強さが最大となっ たが，200以上では低下した. ホウ酸フェニル樹脂 では熱劣化の程度が小さかった。

（4）耐酸化熱分解性は，ホウ酸フェニル樹脂がハロ ゲン系共縮合樹脂, 未変性フェノール樹脂に比べて非 常に優れていた。耐酸化熱分解性に及ぼす変性フェノ 一ル樹脂の効果は $\mathrm{PBP}>\mathrm{GP} \fallingdotseq \mathrm{CLP} \gg \mathrm{BRP}$ の順であ った.

（昭和61年 9 月19日 第30回材料研究連合講演会にて講演）
参 考 文 献

1) 海老原直文, 半田 隆, 材料, 30, 936 (1981).

2) T. Colclough, W. Gerrard and M. F. Lappert, J. Chem. Soc., 907 (1955).

3) U.S.P 2623866.

4) DEAS 1816241.

5) H. Schiff, "Beilstein's Handbuch der Organischen Chemie”, H-6, 183 (1918).

6) DEPS 1233606.

7) 特公昭37-8847.

8）福田明德, 長谷川喜一, 堀内 光, 高分子論文集, 40 , 329 (1983).

9) P.W. King, R.H. Mitchell and A. R. Westwood, J. Appl. Polym. Sci., 18, 1117 (1974).

10）村山新一, “フェノール樹脂”, p. 14 (1970) 日刊工業新 聞社.

11）英一太, “プラスチックの難燃化”, p. 112 (1978) 日 刊工業新聞社.

12）船引恭平, 中村昌之, 釣谷雅明, 熱硬化性樹脂, 2, 220 (1981). 